\title{
Practical Strategies for the Integration of College English Course and Ideological and Political Education
}

\author{
Bing Zhang ${ }^{1, *}$
}

\author{
${ }^{1}$ Department of Foreign Language Teaching, BaiCheng Normal University, Baicheng, 137000, China \\ *Corresponding author.Email: 25182718@qq.com
}

\begin{abstract}
Exploring the practical integration strategy of college ideological and political education and English course education will help college students to establish a correct, healthy and comprehensive social cognitive view in the process of better learning English, which plays a particularly important role in improving the development of students' English learning ability and promoting the better implementation of College ideological and political education. College English teachers should take college English curriculum education as the starting point, seek a more scientific and reasonable integration path in the continuous exploration and practice, and make breakthroughs in the continuous implementation.
\end{abstract}

Keywords: college English course, ideological and political education, practice, elements, exploration

\section{INTRODUCTION}

As one of the public basic courses in higher education, College English classroom teaching occupies a large proportion of students' learning time. On the one hand, based on the development trend of cultural globalization, foreign languages have more and more influence on students' study, life, work and communication. College English curriculum reform plays an important role in students' language learning and course teaching. English classroom teaching is the place where students master English language knowledge. It is beneficial to reform college English classroom teaching according to the theory of "Curriculum Ideology" In order to cultivate students' cross-cultural communication ability, let students understand the western social culture represented by English speaking countries, actively and deeply study the traditional culture of their own country and nation, break through the cultural differences through different thinking, and improve the quality of students' English learning.

\section{THE IMPORTANCE OF IDEOLOGICAL AND POLITICAL EDUCATION IN COLLEGE ENGLISH TEACHING}

To promote the reform of College English teaching from the perspective of "curriculum ideological and political" system is to carry out ideological and political education in the process of English teaching. Through the carrier of College English language learning, while introducing foreign western culture, and using the positive guidance of teachers, students can form a correct sense of thinking, better understand foreign culture, and avoid students from being affected by foreign bad habits Influence, and then form the correct values and outlook on life. Ideological and political education throughout the whole process of learning English language knowledge can break the barriers between disciplines, improve the affinity of Ideological and political education, let students objectively understand foreign culture, and enhance their national cultural self-confidence.

\subsection{Understanding the time value of College English curriculum ideological and political education in moral education}

Young people are in a critical period of forming and establishing their outlook on life and values. Cultivating and practicing socialist core values is an important mission of the current ideological and political education. Therefore, colleges and universities should use socialist core values to educate and influence young students, bury the seeds of truth, goodness and beauty in their hearts, and guide them to buckle the "first button" in their life. As an important part of higher education, College English teaching has the characteristics of more class hours and longer cycle[1]. The integration of Ideological and political education into College English teaching content and implicit way into the life of young students can not only give fresh vitality to the traditional ideological and political education, but also enrich the connotation of English curriculum itself. It is of great importance to excavate the value of College English "Ideological and Political Courses" to the implementation of the fundamental task of moral education and to expand the functions of College English courses in knowledge, thought and skills, so as to cultivate talents needed for the construction of socialism with Chinese characteristics in the new era. Therefore, College English "Ideological and Political Curriculum" has immeasurable value of the times. College English "Ideological and Political Curriculum" makes English 
teaching have a clearer goal and richer connotation. If the original purpose of College English teaching was to let young students understand the world, today's College English teaching has a greater mission, that is, to make young students fully aware of the breadth, profundity and long history of Chinese traditional culture, so as to enhance their cultural confidence on the basis of inheriting the excellent traditional Chinese culture, so as to introduce China and spread Chinese culture to the world, Further carry forward Chinese culture.

\subsection{Guiding young students to learn western culture with critical eyes}

Language is not only the carrier of culture and ideology, but also its media. Language teaching is closely related to the dissemination of culture and ideology. The process of teaching a language is the process of imparting the culture and ideology represented by the language. College English classroom teaching naturally involves the introduction of western culture and ideology. Since modern times, with the success of the industrial revolution and the continuous development of science and technology, western culture tends to be sanctified. Due to their weak judgment, the majority of young people are easily influenced by wrong ideas and do not distinguish and absorb western culture. Therefore, in College English teaching, the integration of "curriculum ideological and political" is particularly important. The majority of English teachers should conscientiously study general secretary Xi Jinping's speech on youth work, guide the teaching work with the concept of youth of general secretary Xi Jinping, attach importance to young people's moral education, and guide young students to critically learn western culture, that is, to recognize what is conducive to our development and progress in western culture, and what is preventing us from moving forward or even guiding us. What goes astray should absorb those positive, progressive, civilized, scientific and beneficial to our development, and combine them with our excellent traditional culture to help us develop and expand[2].

\subsection{Cultivating young students' confidence in national culture}

The construction of "Ideological and Political Courses" is the key to cultivate morality, cultivate builders and successors of socialism with Chinese characteristics. College English teaching bears an irreplaceable responsibility and obligation in the ideological and political aspects of curriculum, and it is also one of the effective carriers of moral education. It is a new and unique way to enhance students' cultural and national self-confidence by critically carrying out western culture education, Chinese traditional culture education and China's national conditions education in the new era. In the novel and unique, the students are imperceptibly infiltrated and baptized by the socialist core values and excellent traditional Chinese culture, and can apply what they have learned to the English context and improve their interest in learning English. Through the ideological and political course of College English, students can not only master the essence of western culture, but also convey our ideology, culture and values at any time. College English "Ideological and political" teaching can make students "not forget the original, absorb foreign, face the future, and better build the Chinese spirit, Chinese value and Chinese strength". Contemporary young students should strengthen their cultural confidence and "tell Chinese stories, spread Chinese voice and interpret Chinese characteristics" to the world. They should not only inherit the excellent traditional Chinese culture, but also carry forward the spirit of the times. They should not only be based on their own country but also face the world. In other words, they should inherit, spread and carry forward the innovative achievements of Chinese traditional culture and modern culture. This is not a one-off process. It needs to be explored and practiced in English classroom teaching in Colleges and universities in a long-term and multidimensional way.

The construction of "Ideological and Political Courses" is the key to cultivate morality, cultivate builders and successors of socialism with Chinese characteristics. College English teaching bears an irreplaceable responsibility and obligation in the ideological and political aspects of curriculum, and it is also one of the effective carriers of moral education. It is a new and unique way to enhance students' cultural and national self-confidence by critically carrying out western culture education, Chinese traditional culture education and China's national conditions education in the new era. In the novel and unique, the students are imperceptibly infiltrated and baptized by the socialist core values and excellent traditional Chinese culture, and can apply what they have learned to the English context and improve their interest in learning English. Through the ideological and political course of College English, students can not only master the essence of western culture, but also convey our ideology, culture and values at any time. College English "Ideological and political" teaching can make students "not forget the original, absorb foreign, face the future, and better build the Chinese spirit, Chinese value and Chinese strength". Contemporary young students should strengthen their cultural confidence and "tell Chinese stories, spread Chinese voice and interpret Chinese characteristics" to the world. They should not only inherit the excellent traditional Chinese culture, but also carry forward the spirit of the times. They should not only be based on their own country but also face the world. In other words, they should inherit, spread and carry forward the innovative achievements of Chinese traditional culture and modern culture. This is not a one-off process. It needs to be explored and practiced in English classroom teaching in Colleges and universities in a long-term and multidimensional way. 


\section{TEACHING CONTENTS AND LINKS, TEACHING METHODS AND ASSESSMENT METHODS}

Under the background of "curriculum ideological and political education", College English teaching puts forward higher requirements for teachers. They need not only strong language teaching ability, but also excellent ideological quality, so as to integrate ideological and political education content into College English education scientifically. In order to promote the innovation of College English teachers' professional knowledge, schools should give priority to ensuring teachers' lifelong learning ability. Teachers with advanced professional knowledge, effective teaching by example are the main way of Ideological and political education. Teachers should also have strong ideological and political ability, fully tap the ideological and political education content in College English teaching materials, and integrate ideological and political literacy cultivation into language teaching[3].

\subsection{Based on the teaching content, excavate the elements of "curriculum ideological and political $^{\prime \prime}$}

First of all, an excellent textbook can not only cultivate students' language skills, but also achieve the purpose of acquiring knowledge, expanding vision, improving ability and cultivating sentiment through rich content. New Horizon College English is a set of teaching materials widely used in Colleges and universities in China. The arrangement is reasonable. The topic selection reflects the strong flavour of the times, profound ideological and cultural connotations. The content is closely related to all aspects of students' life and learning, which is easy to arouse students' thinking and resonance, and has both the instrumental and humanistic nature of language. The concept of "Curriculum Ideology and politics" in College English teaching. Secondly, College English can help students to understand the cultural differences between China and the West while learning language knowledge. College English needs to cultivate students' ability of cross-cultural communication. It is necessary to overcome the differences between Chinese and Western languages and ideas, and correctly understand Chinese and foreign cultural elements. Finally, under the "curriculum ideological and political" system, the new demands of College English teaching must pay attention to the cultivation of students' Ideological and moral character, fully guide the students' thought and culture through the communication of language knowledge and culture in the classroom. Through the comparison of Chinese and Western culture, students can understand the foreign culture more truly and objectively and actively deepen their understanding of national traditional culture. At the same time, language communication can realize cultural edification and ideological and political education of College English.
Using modern teaching methods to improve the teaching level of "Ideological and political course"

It is necessary to innovate teaching methods for College English course to be "Ideological and political". Make good use of the existing English materials, actively introduce the basic concepts of culture and language with the actual cases of cross-cultural communication, and take the basic cultural concepts in the cases and materials as the students' cultural learning objectives, and adopt advanced micro class, MOOC and mobile internet teaching resources for ideological and political education. English teachers can show the typical differences between Chinese and foreign cultures, and pay attention to the discussion of Ideological and cultural differences after class, guide students to look at western culture with an objective attitude, and inherit and disseminate Chinese traditional culture and philosophical thoughts. At the same time, they can also display English propaganda films about the construction of a modern powerful socialist country or China's great power diplomacy. It is easy to catch the eye of college students and attract them to watch. In this process, it not only exercises the oral ability, but also gets the baptism of political education from watching videos. Moreover, this kind of Ideological and political education is easier to accept for college students, reduces their resistance, and helps to improve the efficiency of English teaching and ideological and political education.

\subsection{Innovating the ways of inspection and assessment to consolidate the achievements of "curriculum ideological and political education"}

First of all, teachers should distinguish students differences, guide students to treat cultural conflicts rationally, and actively carry out ideological and political education from the perspective of learning. For example, to carry out lectures, discussions and other activities in the classroom to promote teachers to integrate the ideological and political education content with the teaching content of College English course, so as to build a good focus for College English ideological and political education, so as to facilitate college English teachers to plan and organize classroom teaching[4].

\subsection{The implementation of college English curriculum ideological and Political Education}

"Curriculum ideological and political" is a new concept Many college teachers lack of understanding of it. They confuse "curriculum ideological and political" with "Ideological and Political Curriculum", and think that the construction of "curriculum ideological and political" should be the work of teachers in Marxist college. Therefore, schools should provide teachers with more learning opportunities by "inviting in" and "sending out", so as to clarify the connotation and teaching methods of 
"curriculum ideological and political". In addition to abiding by professional ethics, teachers should also constantly participate in political learning; learn the party's principles and policies and the development situation of the country, so as to improve their ideological awareness and overall concept. Under the situation of "curriculum ideological and political education", colleges and universities should pay attention to the integration of various courses and ideological and political education. In addition to mastering solid English knowledge, College English teachers should also actively study ideological and political courses, pay attention to the national education situation, deeply understand the connotation of socialist core values, and subtly integrate ideological and political elements into College English teaching by mining various resources. The College English teaching department or the teaching and research section should set up a college English "curriculum ideological and political" teaching team, committed to the following aspects of work: first, jointly formulate the implementation plan of College English "curriculum ideological and political" and organize team members to adjust the course construction according to the plan, including revising the syllabus, setting up courses, preparing lessons collectively, etc., It also safeguards the rationality and effectiveness of the construction of "curriculum thinking and politics". Secondly, the members of the organization actively learn Xi Jinping's speech at the National Education Conference and Chen Baosheng's speech at the 2019 National Conference on educational work, and strengthen the teaching research of "curriculum thinking and politics" combined with the school-based practice; thirdly, encourage the teaching team members to actively declare relevant topics in the construction of "Ideological and political education" in College English. On the basis of the project, teaching research should be carried out in a planned way, and the teaching practice should be condensed into theoretical achievements to further feedback teaching. In the "great ideological and political" pattern, both compulsory courses and cultural literacy courses should be consciously close to the construction of "curriculum ideological and political". For example, by introducing ideological and political elements into various courses, students can be guided to learn English versions of Chinese philosophy, religion, folklore, geography and other works, so as to improve students' English skills and cultivate their cultural confidence, national pride and patriotic feelings. As mentioned above, College English textbooks are mainly based on western countries. If we only lead the students to learn the contents of the teaching materials, students will inevitably be affected by the western culture and ideology in the teaching materials, which will lead them to deviate from the socialist core values, and even blindly worship the west, while ignoring the core cultural values of their own country. Therefore, College English education should not only broaden students' international vision and cultivate their English thinking, but also shape students into socialist builders and successors with Chinese feelings. Of course, the integration of Chinese ideological and political elements in College
English teaching is not to negate the ideological value of the West. They can also go together and complement each other to cultivate students' dialectical thinking ability and cultural confidence.

\section{CONCLUSION}

College English, as an important subject for college students to improve their English ability and expand their foreign language knowledge, plays a very important role in laying a foundation for students to better adapt to society and develop themselves. However, there is a problem that English course teaching and ideological and political education teaching are divorced from each other in many colleges and universities. This phenomenon is very prominent in public English teaching. Due to the lack of attention to the guidance of English teaching, many important ideological and political thoughts are difficult to penetrate into students' specific learning behavior, which greatly impacts the cultivation and formation of students Outlook on life, society, values and life. Therefore, College English teachers must pay attention to it. Through the exploration and practice of Ideological and political education teaching of College English course, guide students to form a more healthy and comprehensive personality and ideas, and develop towards a better direction of knowledge. This paper mainly discusses the exploration and practical countermeasures of Ideological and political education in College English from the following aspects. The construction of "Ideological and Political Courses" is the key to cultivate morality, cultivate builders and successors of socialism with Chinese characteristics. College English teaching bears an irreplaceable responsibility and obligation in the ideological and political aspects of the curriculum, and it is also one of the effective carriers of moral education. It is a new and unique way to enhance students' cultural and national self-confidence by critically carrying out western culture education, Chinese traditional culture education and China's national conditions education in the new era. In the novel and unique, the students are imperceptibly infiltrated and baptized by the socialist core values and excellent traditional Chinese culture, and can apply what they have learned to the English context and improve their interest in learning English. Through the ideological and political course of College English, students can not only master the essence of western culture, but also convey our ideology, culture and values at any time. College English "Ideological and political" teaching can make students "not forget the original, absorb foreign, face the future, and better build the Chinese spirit, Chinese value and Chinese strength". Contemporary young students should strengthen their cultural confidence and "tell Chinese stories, spread Chinese voice and interpret Chinese characteristics" to the world. They should not only inherit the excellent traditional Chinese culture, but also carry forward the spirit of the times. They should not only be based on their own country but also face the world. In other words, they should inherit, spread and carry forward the innovative 
achievements of Chinese traditional culture and modern culture. This is not a one-off process. It needs to be explored and practiced in English classroom teaching in Colleges and universities in a long-term and multidimensional way. "Curriculum thinking and politics" is a positive practice of the important speech of the National College Ideological and political work conference, the teachers and Students Symposium of Peking University, the National Education Conference and the teachers' Forum on Ideological and political theory in recent years, guided by Xi Jinping's new socialist ideology with China's characteristics and the important instructions on education. The University integrates ideological and political education into the whole talent training system, adheres to the unity of explicit and implicit ideological and political education, excavates the ideological and political education resources contained in different courses and teaching methods, and realizes the main channel for all staff to educate people in an all-round way and comprehensively improve their talent quality. College education should adhere to the fundamental task of cultivating people with moral integrity, accelerate the pace of educational modernization, actively build a powerful education country, and strive to cultivate socialist builders and successors with all-round development of morality, intelligence, physique, beauty and labor. Moral education is not a day's work. Colleges and universities should make a long-term preparation for the "curriculum ideological and political" work, understand the time value of "curriculum ideological and political" from a high position, clarify the profound connotation of "curriculum ideological and political" in a multidimensional way, and promote the practical exploration of "curriculum ideological and political" in an all-round way. In the process of College English teaching, we should first recognize the time value of College English "Ideological and political course" in moral education. Secondly, we should guide young students to learn western culture with a critical eye. Finally, we should cultivate young students' confidence in national culture.

\section{REFERENCES}

[1] Li Bo, Exploration and practice of "curriculum ideological and political education" in College English Teaching. Curricum Education Research. 2018, pp. 3638

[2] Jin Lei. Northern lights, Research on the effective path of Integrating Ideological and political elements into higher vocational English Teaching in the new era. 2019, pp. $25-28$

[3] Cai Jigang, On the instrumental and humanistic nature of foreign language teaching from the perspective of language attributes. Journal of Northeast Normal University (PHILOSOPHY AND SOCIAL SCIENCES). 2017, pp.45-47

[4]Yu Ying, Research on "Online+offline" two-way interactive College English teaching mode based on network resources. Campus English. 2017, pp. 5-47. 